\title{
Consistency Arrangement of Absolute Power of Attorney in Transfer of Rights to Land
}

\author{
Assist. Prof. DR. Farid, S. H. M. H. M. Kn.* \\ Assistant Professor, Faculty of Law, Sultan Agung Islamic University, Indonesia
}

*Corresponding author: Assist. Prof. DR. Farid, S.H. M. H. M. Kn, ORCID ID 0000-0003-03724963, Faculty of Law, Sultan Agung Islamic University, Attorney Independent, Legal Consultant, Intellectual \& Property Rights, Indonesia, Email: faridbbs75@gmail.com

\author{
Mini Review \\ Volume 3 Issue 4
}

Received Date: September 26, 2020

Published Date: October 12, 2020

DOI: $10.23880 /$ abca-16000141

\section{Abstract}

The Agreement to Give Absolute Power of Attorney or better known as the Absolute Power of Attorney (Absolute Power of Attorney), is not known in the Civil Code. Even though the Civil Code does not recognize him, the existence of an Absolute Power of Attorney is not prohibited. The articles in Book III of the Civil Code are only complementary, the parties are allowed to deviate from them. So that if the parties involved in the power-giving agreement want absolute power, then this is allowed and not prohibited by the Civil Code. Because in principle, contract law is open (freedom of contract principle) and legal certainty principle.

Keywords: Absolute Power of Attorney; Power Agreement; Contract Law

\section{Mini Review}

The Power of Attorney Agreement is a legal institution regulated in Book III of Article 1792 to Article 1819 of the Civil Code [1]. In Article 1792 of the Civil Code, it is stated that: The granting of power is an agreement whereby a person gives power to another person, who receives it, to carry out an affair on his behalf. The power grant agreement in its development has become broad, but in this research it only examines the absolute power of the notary in the transfer of land rights. The approach method used in this research is juridical normative which examines secondary data in the form of positive law related to absolute power.

This research is descriptive analytical, which describes the problem regarding the process of transferring land rights based on absolute power made by a notary. The results of the research show that the process of transferring land rights based on absolute power is prohibited in practice by Article 39 paragraph 1 letter d of Government Regulation. Republic of Indonesia Number 24 of 1997 concerning Land Registration
[2]. This Article determines that the Land Deed Making Official refuses to make the deed, if one of the parties or the parties acts on the basis of an absolute power of attorney which essentially contains the legal acto ftransferring rights.

What is meant by Absolute Power of Attorney according to this Article, in its explanation it explains that what is meant by Absolute Power of Attorney is the provision of power of attorney which cannot be withdrawn by the party giving the power of attorney or cannot be terminated by any cause and which in essence is a legal act of transfer of rights. From the elucidation of Article 39 paragraph 1 letter $d$ of the Government Regulation of the Republic of Indonesia Number 24 of 1997 concerning Land Registration, it can be concluded that the Official for Making Land Deeds is prohibited from carrying out the process of transferring land rights based on an Absolute Power of Attorney.

The Agreement to Give Absolute Power of Attorney or 
better known as the Absolute Power of Attorney (Absolute Power of Attorney), is not known in the Civil Code. Even though the Civil Code does not recognize him, the existence of an Absolute Power of Attorney is not prohibited. The Civil Code only recognizes two types of agreement granting power of attorney, namely general power and special power. According to Article 1795 of the Civil Code [3], it is stated that the granting of power of attorney can be carried out specifically, namely regarding only one or more specific interests, or in general, namely covering all the interests of the grantor of power.

The articles in the contract law are only as a complement, the parties are allowed to deviate from them. So that if the parties involved in the power-giving agreement want absolute power, then this is allowed and not prohibited by the Civil Code. Because in principle, contract law is open (freedom of contract principle) and legal certainty principle. In the provisions of civil procedural law or better known as H.I.R./R.I.B. -also does not know the term absolute power. According to Article $123 \mathrm{H}$. I. R / R. I. B [4], the definition of giving special power is that a special power of attorney (agreement to grant special power) is a person who with a separate (special) power of attorney is empowered to represent the case. This means that such power of attorney is commonly used by advocates to proceed in court.

This so-called absolute power of attorney arises in legal practice, which is intended for the purpose of dealing with an interest. The legal basis for making and granting power of attorney like this is the freedom of contract that is adopted in civil law, the limitations of which are regulated in Article 1338 in conjunction with Article 1320 of the Civil Code [5]. In practice, this absolute power of attorney is stated in the form of a notary deed as a party deed. Some use the title "sale and purchase agreement/bond" or "power to sell". There are several reasons why people prefer to make an absolute power of attorney, not a sale and purchase certificate, namely [6]:

- The landowner has already borrowed money from the owner of the capital at a high enough interest so that when the debt cannot be paid off, an absolute power of attorney is drawn up.

- Land certificates are incomplete, so the sale and purchase cannot be carried out. At that time there were only girik letters.

Other reasons that caused the community to choose to make absolute power in the transfer of land rights were:

- The buyer will sell the land to someone else.

- The buyer does not have the money to pay the agreed price.

Absolute Power of Attorney is a form of agreement granting power of attorney, so that in its creation it must comply with and be based on the general terms and conditions (principles) contained in Book III- Concerning EngagementBook of Civil Law. Not subject to and based on other provisions outside the Civil Code. This is confirmed in Article 1319 of the Civil Code [7], that all agreements, whether they have a special name, or those that are not known by a certain name, are subject to general regulations, which are contained in this chapter and the last chapter. From the provisions of this Article, it can be concluded that the Civil Code in Indonesia is the highest source of contract law. So that other regulations per law that want to regulate agreements must comply with and refer to the general provisions (including the terms of the validity of the agreement) in Book III of the Civil Code.

In the past, absolute power was stated in Article 3 of the blank Deed of Sale and Purchase of land. Absolute power can also be found in the deed of power to install Mortgages based on Article 1178 paragraph (2) of the Civil Code, and in the sale and purchase agreement. Currently, absolute power can still be seen in the form of power of attorney to impose mortgage rights and a memorandum of sale and purchase agreement. In Article 15 paragraph 2 of Law of the Republic of Indonesia No.4 of 1996 concerning Mortgage Land and Objects related to Land [8], it is stated that the power to impose mortgage rights cannot be withdrawn or cannot be terminated for any reason except because the power has been confirmed. implemented or because the period has expired. From the provisions contained in Article 15 paragraph 2, it can be concluded that the existence of Absolute Power is not prohibited. Based on this description, the authors argue that it is evident that there are two conflicting regulations per Invitation, in terms of the arrangement of Absolute Power of Attorney.

Namely the explanation of Article 39 paragraph 1 letter $\mathrm{d}$ of Government Regulation. Republic of Indonesia Number 24 of 1997 concerning Land Registration, prohibits the use of an Absolute Power of Attorney which is for the transfer of land rights. While the Law of the Republic of Indonesia No.4 of 1996 Namely the explanation of Article 39 paragraph 1 letter d of Government Regulation. Republic of Indonesia Number 24 of 1997 concerning Land Registration, prohibits the use of an Absolute Power of Attorney which is for the transfer of land rights. While the Law of the Republic of Indonesia No.4 of 1996 concerning Mortgage Rights to Land and Objects related to Land, Article 15 paragraph 2 does not prohibit. This proves that in Indonesia, which is a state based on the rule of law, there is still disharmony of regulations per the Invitation Law.

In the author's opinion that absolute power is a legal act of an agreement granting power of attorney that does not contradict the Civil Code, as long as it is made legally, in 
accordance with the provisions of Article 1320 of the Civil Code. The existence of absolute power, even permitted and regulated in Article 15 paragraph (2) of Law No. 4 of 1996 concerning Mortgage Rights to Land and Objects related to Land [9]. J. Satrio emphasized in his book, that: The law itself stipulates that the power to impose Mortgage Rights is absolute power. Thus, the provision of an irrevocable power of attorney is valid if the agreement on which the power of attorney is based has a valid legal basis (title).

The existence of Article 39 paragraph 1 letter d Government Regulation. The Republic of Indonesia Number 24 of 1997 concerning Land Registration, does not create order and legal certainty, as the stated objectives in its preamble. On the contrary, it creates legal instability, creates an absence of legal order, proves the absence of legal harmonization, gives birth to conflicting/overlapping laws, which in the end, certainty, benefit and justice will not be realized. The existence of Article 39 paragraph 1 letter $d$ Government Regulation. The Republic of Indonesia Number 24 of 1997 concerning Land Registration is contrary to the principles of contract law, namely contrary to the principle of freedom of contract and the principle of certainty as contained in Article 1338 of the Civil Code. Also contrary to Article 1319 of the Civil Code and contrary to Article 15(2) Law No. 4 of 1996 concerning Mortgage Rights on Land and Objects related to Land.

Hierarchically per Invitation as adopted in the Legal System in Indonesia, namely in Law Number 15 of 2019 concerning Amendments to Law of the Republic of Indonesia number 12 of 2011 concerning the Establishment of Per-Invitation Regulations, the existence of Government Regulations. Republic of Indonesia Number 24 Year 1997 regarding Land Registration, is under Law No. 4 of 1996 concerning Mortgage Rights to Land and Objects related to Land and under the Civil Code. So that in accordance with the Principle of Lex Superior Derograt Legi Priori, the existence of Article 39 paragraph 1 letter d of Government Regulation. Republic of Indonesia Number 24 Year 1997 regarding Land Registration, becomes null and void by law.

The meaning of this principle is that a lower statutory regulation may not contradict higher laws and regulations. If that happens, the lower legislation will be null and void. From this principle, it can be concluded that each statutory regulation must be compatible with each other, mutually related, not mutually contradicting or overlapping. So that it will reflect the harmonization of laws and regulations in the legal system in Indonesia.

Based on the research results as described above, the author concludes that the existence of Article 39 paragraph 1 letter d of Government Regulation. Republic of Indonesia Number 24 of 1997 concerning Land Registration, is null and void and has no binding legal force.

Furthermore, the author suggests that Government Regulation. Republic of Indonesia Number 24 of 1997 concerning Land Registration, in particular Article 39 paragraph 1 letter $\mathrm{d}$ for revision, in order to achieve harmonization of regulations per Invitation as mandated by Law Number 15 of 2019 concerning Amendments to Law of the Republic of Indonesia number 12 of 2011 concerning the Formation of Per Invitation Regulations. So that the principles of legal certainty, the principles of benefit, and justice can be created.

\section{References}

1. Subekti RSH, Tjitrosudibio R (1992) Kitab Undang Undang Hukum Perdata. Jakarta: Pradnya Paramita PT, pp: 282.

2. (1997) Peraturan Pemerintah Republik Indonesia Nomor 24 Tahun 1997. Tentang Pendaftaran Tanah.

3. Subekti RSH, Tjitrosudibio R (1992) Kitab Undang Undang Hukum Perdata. Pradnya Paramita, Jakarta, pp: 383 .

4. Soesilo R (1985) RIB/HIR Dengan penjelasan. Politea, pp: 81-82.

5. Harifin AT (1997) Surat Kuasa Mutlak. Varia Peradilan Tahun XII Nomor 142, pp: 132.

6. Harifin AT (1942) Op. Cit, pp: 132.

7. Subekti RSH, Tjitrosudibio R (1992) Kitab Undang Undang Hukum Perdata, Pradnya Paramita: Jakarta, pp: 283.

8. Undang-Undang Republik Indonesia Nomor 4 Tahun 1996 Tentang Hak Tanggungan Atas Tanah Beserta Benda yang Berkaitan dengan Tanah; 1996 Semarang Badan Penerbit Universitas Diponegoro.

9. Satrio J (2004) Hukum Jaminan, Hak Jaminan Kebendaan, Hak Tanggungan Buku 2. Bandung, pp: 187.

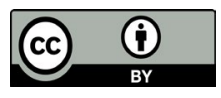

